\title{
ANALISIS PROSES PENGADAAN BARANG DAN JASA BERDASARKAN PERPRES NO. 54 TAHUN 2010 TENTANG PENGADAAN BARANG DAN JASA
}

\author{
Lintje Anna Marpaung 1 , S. Endang Prasetyawati², Baskoro Budihardjo ${ }^{3}$ \\ Program Magister Hukum \\ Universitas Bandar Lampung \\ Jl. ZA Pagar AlamNo. 89, Gedong Meneng, Bandar Lampung
}

Email: lintje@ubl.ac.id; s.endang_prasetyawati@gmail.com;

baskoro.budiharjo@studentubl.ac.id

\begin{abstract}
Abstrak
Kuasa Pengguna Anggaran (KPA) yang ada di masing-masing Kementrian/Lembaga/Daerah/ Institusi berwenang membelanjakan dana DIPA (Daftar Isian Pelaksanaan Anggaran) dalam mengadakan barang dan jasa di lingkungannya, dalam pelaksanaan pengadaan barang dan jasa tersebut pemerintah telah mengatur mekanisme penggunaan dana negara dengan menerbitkan Perpres No. 54 Tahun 2010 tentang pengadaan barang dan jasa, 3 metode penyedia pengadaan barang dan jasa yaitu pengadaan langsung, lelang sederhana dan penunjukan langsung serta menjelaskan syarat-syarat khusus dapat dilaksanakannya proses penunjukan langsung sesuai dengan Perpres No. 54 Tahun 2010 Pasal 38 ayat 4 tentang pengadaan barang dan jasa, Kuasa Pengguna Anggaran dapat lebih memahami syarat khusus penunjukan langsung di dalam Perpres No. 54 Tahun 2010 tentang Pengadaan Barang dan Jasa.
\end{abstract}

Kata Kunci : Proses, pengadaan barang, jasa 


\section{Pendahuluan}

Demi kelancaran dan ketersediaan barang dan jasa di lingkungan pemerintah negara republik indonesia, pemerintah telah mengalokasikan anggaran belanja negara yang dituangkan kedalam DIPA (Daftar Isian Pelaksanaan Anggaran) masing masing satuan kerja di lingkungan pemerintahan negara Indonesia .

Dalam pelaksanaan pengadaan barang dan jasa tersebut pemerintah telah mengatur mekanisme penggunaan dana negara dengan menerbitkan Perpres No. 54 tahun $2010^{1}$ tentang pengadaan barang dan jasa pemerintah.

Tata pemerintahan yang baik dan bersih (good governance and clean government) adalah seluruh aspek yang terkait dengan kontrol dan pengawasan terhadap kekuasaan yang dimiliki oleh Pemerintah dalam menjalankan fungsinya melalui institusi formal dan informal. Pengadaan sebagai pelaksana dari pelaksana Kuasa Pengguna Anggaran (KPA), harus menghasilkan barang/jasa yang dapat dipertanggung jawabkan kepada masyarakat dari segi administrasi, teknis, dan keuangan. Oleh karena itu,proses pengadaan harus dilaksanakan dengan perinsip sebagai berikut :

1. Efisien, berarti pengadaan harus diusahakan dengan

${ }^{1}$ Tim visimedia, Konsolidasi paling updete peraturan presiden tentang pengadaan barang dan jasa, visi media, jakarta, 2015, hlm 5 menggunakan dana dan daya minimum untuk mencapai kualitas dan sasaran dalam waktu yang ditentukan atau menggunakan dana yang telah ditetapkan untuk mencapai hasil dan sasaran dengan kualitas yang maksimum.

2. Efektif, berarti pengadaan harus sesuai dengan kebutuhan dan sasaranyang telah ditetapkan serta memberikan manfaat yang seluas luasnya.

3. Tansparan, berarti semua ketentuan dan informasi mengenai pengandaan bersifat jelas dan dapat diketahui secara luas oleh penyedia barang/jasa yang berminat, serta oleh masyarakat pada umumnya.

4. Terbuka, berarti pengadaan dapat diikuti oleh semua penyedia barang/jasa yang memenuhi persyaratan/kriteria tertentu berdasarkan ketentuan dan prosedur yang jelas.

5. Bersaing, berarti pengadaan harus dilakukan melalui persaingan yang sehat diantara sebanyak mungkin penyedia barang/jasa yang setara dan memenuhi persyaratan sehingga dapat diperoleh barang/jasa yang ditawarkan secara kompetitif dan tidak ada interfensi yang mengganggu terciptanya mekanisme pasar dalam pengadaan. 
6. Adil/Tidak diskriminatif, berarti memberikan perlakuan yang sama bagi semua calon penyedia barang/jasa dan tidak mengarah pada keuntungan pihak tertentu dengan tetap mengutamakan kepentingan nasional.

7. Akuntabel, berarti harus sesuai dengan aturan dan ketentuan yang terait dengan pengadaan sehingga dapat dipertanggung jawabkan. ${ }^{2}$

Menurut Perpres No. 54 Tahun 2010 terdapat unsur-unsur pelaksana proses pengadaan barang/jasa diantaranya:

1. Pengguna anggaran yang selanjutnya disebut PA adalah pejabat pemegang kewenangan penggunan anggaran Kementrian/Lembaga/Daerah/Ins titusi pengguna APBN/APBD.

2. Kuasa Pengguna Anggaran selanjutnya disebut KPA adalah pejabat yang ditetapkan oleh PA untuk menggunakan APBN atau ditetapkan oleh Kepala Daerah Untuk menggunakan APBN.

3. Pejabat pembuat komitmen yang selanjutnya disebut PPK adalah pejabat yang bertanggung jawab atas terlaksananya pengadaan barang/jasa

Unit Layanan Pengadaan yang selanjutnya disebut ULP adalah unit organisasi

Kementrian/Lembaga/Daerah/I nstitusi, yang berfungsi mengadakan pengadaan barang/jasa yang bersifat permanen, dapat berdiri sendiri

${ }^{2}$ Agus kuncoro, menang tender pengadaan barang dan jasa, Pt Wahyu Media, jakarta 2011, hlm 14-15 atau melekat pada unit yang sudah ada.

4. Pejabat pengadaan adalah personil yang ditunjuk untuk melaksanakan pengadaan langsung, penunjukan langsung, E-Purchasing

5. Panitia/Pejabat Penerima Hasil Pekerjaan adalah panitia/pejabat yang ditetapkan oleh PA/KPA yang bertugas memeriksa dan menerima hasil pekerjaan.

Menurut Perpres No. 54 Tahun 2010 Pasal 1 tentang pengadaan barang dan jasa, yang dimaksud dengan pengadaan barang dan jasa adalah kegiatan untuk memperoleh barang/jasa oleh Kementrian/Lembaga/Satuan kerja perangkat daerah/institusi yang prosesnya dimulai dari perencanaan kebutuhan sampai diselesaikannya seluruh kegiatan untuk memperoleh barang/jasa ${ }^{3}$.

Pengadaan barang dan jasa pemerintah terbagi menjadi dua rencana pelaksanaan pengadaan barang dan jasa pemerintah tidak melalui penyedia barang/jasa dan pengadaan barang dan jasa melaluiPengadaan barang dan jasa tidak melalui penyedia barang/jasa yaitu swakelola. Swakelola merupakan kegiatan pengadaan barang/jasa dimana pekerjaannya direncanakan, dikerjakan, dan/atau diawasi sendiri oleh K/L/D/I sebagai penanggung jawab anggarn, instansi pemerintah lain dan/atau kelompok masyarakat. ${ }^{4}$

${ }^{3}$ Ibid, hlm 15

${ }^{4}$ Ibid, hlm 29 
Sedangakan pengadaan barang/jasa melalui penyedia barang/jasa terbagi menjadi 4(empat) metode pemilihan yaitu :

1. pemilihan penyedia barang dilakukan dengan:
a.. Pelelangan umum
b. Pelelangan terbatas
c. Pelelangan sederhana
d. Penunjukan langsung
e. Pengadaan langsung, atau
f. Kontes

2. Pemilihan penyedia pekerjaan konstruksi dilakukan dengan:
a. Pelelangan umum
b. Pelelangan terbatas
c. Pemilihan langsung
d. Penunjukan langsung; atau
e. Pengadaan langsung

3. Pemilihan penyedia jasa lainnya dilakukan dengan
a. Pelelangan umum
b. Pelelangan sederhana
c. Penunjukan langsung
d. Pengadaan langsung; atau
e. Sayembara

4. Kontes/sayembara dilakukan khusus untuk pemilihan penyediabarang/jasa lainnya yang merupakan hasil industri kreatif, inovatif, dan budaya dalam negeri ${ }^{5}$

\section{Pembahasan}

Salah satu tugas pemerintah adalah untuk memajukan kesejahteraan umum. Di satu sisi pemerintah memiliki kewenangan berdasarkan undang undang untuk memungut pajak guna membiayai pelaksanaan tugas tersebut, di sisi lain pemerintah juga harus membelanjakan dana yang dipungut berdasarkan kaidah kaidah tertentu agar terwujudnya pemerintahan yang bersih.

Didalam membelanjakan uang negara pemerintah membuat Perpres No. 54 Tahun 2010 tentang pengadaan barang/jasa pemerintah.

Pengadaan barang/jasa adalah kegiatan untuk memperoleh barang/jasa oleh Kementrian/Lembaga/Daerah/dan Institusi lainnya yang prosesnya dimulai dari perencanaan kebutuhan sampai diselesaikannya seluruh kegiatan untuk memperoleh barang/jasa.

\section{Pengadaan barang/jasa menurut para ahli}

\begin{abstract}
Bahwa pengadaan adalah perolehan barang atau jasa. Hal ini menguntungkan bahwa barang/jasa yang tepat dan bahwa mereka yang dibeli dengan dengan biaya terbaik untuk mememenuhi kebutuhan pembeli dalam hal kualitas dan kuantitas, waktu dan lokasi.
\end{abstract}

\section{Christopher \& Schoole (2007)}

Pengadaan adalah kegiatan untuk mendapatkan barang atau jasa secara transparan, efektif dan efisien sesuai dengan kebutuhan dan keinginan penggunanya.

Edquist et al (2000) 
Pada perinsipnya pengadaan publik (Public Procurement) adalah proses akuisisi yang dilakukan oleh pemerintah dan istitusi publik untuk mendapatkan barang (goods), bangunan (woorks), dan jasa (services) secara transparan, efektif, dan efisien sesuai dengan kebutuhan dan keinginan pengguna. ${ }^{6}$

Dari Pengertian pengertian diatas,dapat disimpulkan bahwa pengadaan barang/jasa adalah suatu kegiatan untuk mendapatkan barang dan jasa yang diperlukan oleh perusahaan dilihat dari kebutuhan penggunaannya, serta dilihat dari kualitas, kuantitas, waktu pengiriman dan harga.

Pengadaan barang dan jasa harus dilaksanakan berdasarkan prinsip-prinsip pengadaan yang dipraktekkan secara Internasional, Efisien, Efektif, persaingan sehat, keterbukaan, transparansi, tidak diskriminatif, dan akuntabilitas. $^{7}$

1. Efisien, berarti pengadaan harus diusahakan dengan menggunakan dana dan daya minimum untuk mencapai kualitas dan sasaran dalam waktu yang ditentukan atau menggunakan dana yang telah ditetapkan untuk mencapai hasil dan sasaran dengan kualitas yang maksimum.

\footnotetext{
${ }^{6}$ Jurnalissekolahku.blogspot.com, diakses pada hari senin, tanggal 19 Februari, pukul 23.00Wib.

${ }^{7}$ Budiharjo Hardjowidjoyo dan Hayie Muhammad, perinsip dasar dan kerangka hukum pengadaan barang/jasa pemerintah, jakarta, 2008
}

2. Efektif, berarti pengadaan harus sesuai dengan kebutuhan dan sasaranyang telah ditetapkan serta memberikan manfaat yang seluas luasnya.

3. Tansparan, berarti semua ketentuan dan informasi mengenai pengandaan bersifat jelas dan dapat diketahui secara luas oleh penyedia barang/jasa yang berminat, serta oleh masyarakat pada umumnya.

4. Terbuka, berarti pengadaan dapat diikuti oleh semua penyedia barang/jasa yang memenuhi persyaratan/kriteria tertentu berdasarkan ketentuan dan prosedur yang jelas.

5. Bersaing, berarti pengadaan harus dilakukan melalui persaingan yang sehat diantara sebanyak mungkin penyedia barang/jasa yang setara dan memenuhi persyaratan sehingga dapat diperoleh barang/jasa yang ditawarkan secara kompetitif dan tidak ada interfensi yang mengganggu terciptanya mekanisme pasar dalam pengadaan.

6. Adil/Tidak diskriminatif, berarti memberikan perlakuan yang sama bagi semua calon penyedia barang/jasa dan tidak mengarah pada keuntungan pihak tertentu .

Tugas dari bagian pengadaan barang adalah menyediakan barang maupun jasa dengan harga yang murah, kualitas dan terkirim tepat waktu. Tugas -tugas bagian pengadaan barang tidak terbatas hanya pada kegiatan rutin pembelian. Tugas-tugas bagian pengadaan barang/jasa adalah sebagai berikut 
1. Merancang hubungan yang tepat dengan supplier (penyedia barang/jasa)

2. Memilih Supplier (penyedia barang/jasa)

3. Memilih dan mengimplementasikan teknologi yang cocok

4. Memelihara data Kebutuhan barang/jasa dan supplier (penyedia barang/jasa )

5. Melakukan proses pembelian

6. Mengevaluasi kinerja supplier (Penyedia barang/Jasa) ${ }^{8}$

Pengadaan langsung adalah pengadaan barang/jasa langsung kepada penyedia barang/jasa, tanpa melalui pelelangan/seleksi/penunjukan langsung Pengadaan langsung dapat dilakukan terhadap pengadaan barang/pekerjaan konstruksi/jasa lainnya yang bernilai paling tinggi Rp 200.000.000; dengan ketentuan:

1. Kebutuhan operasional $\mathrm{K} / \mathrm{L} / \mathrm{D} / \mathrm{I}$;

2. Teknologi sederhana;

3. Resiko kecil;dan/atau

4. Dilaksanakan oleh penyedia barang/jasa usaha orang perseorangan dan/atau badan usaha kecil sedang koperasi kecil,kecuali untuk paket pekerjaan yang menuntut kompetensi teknis yang tidak dapat dipenuhi oleh usaha mikro,usaha kecil,dan koperasi kecil. $^{9}$

${ }^{8} \mathrm{http} /$ /xerma.blogspot.co.id. much.mizanul achlaq 2011, pengertian procurement pengadaan barang, diakses senin tgl 19 februari 2018, pukul $22.00 \mathrm{wib}$

${ }^{9}$ lbid,hlm 41
Sedangkan untuk pengadaan pekerjaan yang tidak kompleks diatas $\mathrm{Rp}$ 200.000.000; (dua ratus juta rupiah) dan bernilai paling tinggi $\mathrm{Rp}$ 5.000.000.000; (lima milyar rupiah) dapat dilakukan dengan pelelangan sederhana paska kualifikasi (dokumen kwalifikasi dievaluasi setelah evaluasi administrasi, teknis dan harga telah dilaksanakan) diumumkan sekurang kurangnya di website kementrian/lembaga/pemerintah daerah/institusi, papan pengumuman resmi untuk masyarakat dan portal pengadaan nasional melalui LPSE, sehingga masyarakat luas dan dunis usaha yang berminat dan memenuhi kualifikasi dapat mengikutinya sehingga perinsip perinsip pengadaan barang/jasa yang efisien, efektif, transparan, terbuka, kompetitif, adil dan akuntabel dapat terpenuhi.

Selain metode tersebut diatas, pengadaan barang/jasa dapat juga dilakukan dengan cara penunjukan langsung, mesikipun nilai pengadaan barang/jasa tersebut lebih dari Rp.200.000.000,- (Dua Ratus Juta Rupiah)

Menurut Pasal 38 ayat (1) (satu) Perpres No. 54 Tahun 2010 Penunjukan langsung terhadap 1 (satu) barang/pekerjaan konstruksi/jasa lainnya dapat dilakukan dalam hal:

a. Keadaan tertentu ; dan/atau

b. Pengadaan barang khusus/pekerjaan konstruksi khusus/jasa lainnya yang bersifat khusus.

Menurut Pasal 38 ayat (4) (empat) "Kriteria tertentu yang memungkinkan dilakukan penunjukan langsung terhadap penyediaBarang/Pekerjaan

Konstruksi/Jasa Lainnya sebagaimana 
dimaksud pada ayat (1) (satu) huruf a meliputi :

a. Penanganan darurat yang tidak dapat direncanakan sebelumnya dan waktu penyelesaiaanya harus segera dan tidak dapat ditunda untuk :

1) Pertahanan negara;

2) Keamanan dan ketertiban masyarakat;

3) Keselamatan atau perlindungan masyarakat yang pelaksanaan pekerjaannya tidak dapat ditunda/harus dilakukan segera,termasuk :

a) Akibat bencana alam dan/atau bencana-non alam dan/atau bencana sosial

b) Dalam rangka pencegahan bencana; dan/atau

c) Akibat kerusakan sarana sarana dan prasaranana yang Dapat menghentikan pelayanan publik

b. Pekerjaan penyelenggaraan penyiapan konferensi yang mendadak untuk menindak lanjuti komitmen internasional dan dihadiri oleh presiden/wakil presiden;

c. Kegiatan menyangkut pertahanan negara yang ditetapkan oleh mentri pertahanan serta kegiatan yang menyangkut keamanan dan ketertiban masyarakat yang ditetapkan oleh Kepala Kepolisian Negara Republik Indonesia

d. Barang/Pekerjaan konstruksi/Jasa lainnya yang spesifik dan hanya dapat dilakukan oleh 1 (satu) penyedia barang /jasa lainnya karena 1 (satu) pabrikan, 1 (satu) pemegang hak paten, atau pihak yang telah memegang ijin dari pemegang hak paten.

\section{Teori Kebijakan Publik}

R.Dye mendefinisikan kebijakan publik sebagai "Whatever governmen choose to do or not to do", yaitu sesuatu apapun yang dipilih oleh pemerintah untuk dilakukan atau tidak dilakuan.

Dye juga mengatakan apabila pemerintah memilih untuk melakukan sesuatu tindakan ,maka tindakan tersebut harus memiliki tujuan, baik yang dilakukan oleh pemerintah maupun yang tidak dilakukan oleh pemerintah harus memiliki dampak di dalam masyarakat

Sedangkan kebijakan publik menurut David Easton adalah sebagai: "Pengalokasian nilai-nilai kepada seluruh masyarakat secara keseluruhan" Pengertian lainnya dari kebijakan publik adalah merupakan rumusan keputusan Pemerintah yang menjadi pedoman guna mengatasi masalah publik yang mempunyai tujuan, rencana dan program yang akan dilaksanakan secara jelas.

Kebijakan publik merupakan pengembangan dari kebijakan yang dilakukan oleh pemerintah dan aparaturnya. ${ }^{10}$

Kebijakan publik pada dasarnya adalah suatu keputusan yang dimaksudkan untuk mengatasi kesalahan tertentu melakukan kegiatan tertentu, dan untuk mencapai tujuan tertentu yang dilakukan oleh intansi yang memiliki wewenang

${ }^{10}$ Nyimas dwi koryati dkk, kebijakan dan manajemen pembangunan wilayah, Yogyakarta $2005 \mathrm{hlm} 7$ 
dalam rangka penyelenggaraan tugas pemerintah Negara dan pembangunan, berlangsuang dalam satu kebijakan tertentu .

Dalam kehidupan administrasi negara, secara formal, keputusan tersebut lazimnya dituangkan dalam berbagai bentuk peraturan Perundang-undangan.

Masalah publik dapat dibedakan dalam masalah prosedural yaitu bagaimana pemerintah diorganisasikan dan bagaimana pemerintah melakukan tugas tugasnya ${ }^{11}$.

Dengan melihat definisi tersebut kebijakan publik dapat dibedakan menjadi dua: kebijakan publik dalam peraturan tertulis (Peraturan Perundang-undangan), dan peraturan yang tidak tertulis namun disepakati bersama.

Dalam peraturan Tertulis, tingkat kebijakan publik di Indonesia dapat dibedakan menjadi 3 (Tiga), yaitu antara lain :

1. Kebijakan Publik Tertinggi adalah kebijakan publik yang mendasari dan menjadi falsafah dari terbentuknya Negara Kesatuan Republik Indonesia, yaitu Pancasila dan UndangUndang Dasar (UUD) 1945 yang merupakan produk pendiri bangsa indonesia, Yang hanya dapat di revisi oleh Majelis Permusyawaratan Rakyat (MPR) sebagai perwujudan dari seluruh rakyat Indonesia

2. Kebijakan Publik yang kedua adalah yang dibuat dalam bentuk kerjasama antara legislatif dan eksekutif.Model

11 Teodore Lowi dalam Winarno, kebijakan publik ( public policy), bandung 2002 hlm 51 ini bukan menyiratkan ketidak mampuan legislatif, namun menyiratkan tingkat kompleksitas permasalahan yang tidak memungkinkan legislatif bekerja sendiri. Contoh kebijakan publik yang dibuat bersama antara legislatif dan eksekutif ini adalah Undang-undang dan perarturan daerah.

3. Kebijakan publik yang ketiga adalah kebijakan publik yang dibuat oleh eksekutif saja. Didalam perkembangannya, peran eksekutif tidak cukup melaksanakan kebijakan yang dibuat oleh legislatif, karena produk dari legislatif berisiskan permasalahan yang luas/umum, sehingga dibutuhkan peraturan pelaksanaan yang dibuat sebagai turunan dari produk peraturan legislatif,contoh perturan yang dibuat oleh eksekutif adalah peraturan pemerintah (PP), Keputusan/Peraturan Presiden (Kepres/Perpres),

Keputusan/Peraturan Mentri (Kepmen/Permen),

Keputusan/Peraturan Gubernur hingga kepala daerah.

Berdasarkan keseluruhan uraian maupun pengertian yang disebutkan diatas, maka dapat diartikan bahwa pengertian kebijakan publik dalam proses pengadaan barang/jasa pemerintah adalah apa-apa yang diputuskan oleh pemerintah untuk dikerjakan maupun tidak dikerjakan demi mensejahterakan masyarakat.

\section{Penutup.}


Menurut Perpres No. 54 Tahun 2010

Pasal 1 tentang pengadaan barang dan jasa, yang dimaksud dengan pengadaan barang dan jasa adalah kegiatan untuk memperoleh barang/jasa oleh Kementrian/Lembaga/Satuan kerja perangkat daerah/institusi yang prosesnya dimulai dari perencanaan kebutuhan sampai diselesaikannya seluruh kegiatan untuk memperoleh barang/jasa.

Pengadaan langsung adalah pengadaan barang/jasa langsung kepada penyedia barang/jasa, tanpa melalui pelelangan/seleksi/penunjukan langsung Pengadaan langsung dapat dilakukan terhadap pengadaan barang/pekerjaan konstruksi/jasa lainnya yang bernilai paling tinggi Rp 200.000.000; dengan ketentuan:

1. Kebutuhan operasional K/L/D/I ;

2. Teknologi sederhana;

3. Resiko kecil;dan/atau

4. Dilaksanakan oleh penyedia barang/jasa usaha orang perseorangan dan/atau badan usaha kecil sedang koperasi kecil,kecuali untuk paket pekerjaan yang menuntut kompetensi teknis yang tidak dapat dipenuhi oleh usaha mikro,usaha kecil, dan koperasi kecil.

Sedangkan untuk pengadaan pekerjaan yang tidak kompleks di atas Rp 200.000.000; (dua ratus juta rupiah) dan bernilai paling tinggi Rp 5.000.000.000; (lima milyar rupiah) dapat dilakukan dengan pelelangan sederhana paska kualifikasi (dokumen kwalifikasi dievaluasi setelah evaluasi administrasi, teknis dan harga telah dilaksanakan) diumumkan sekurang kurangnya di website

kementrian/lembaga/pemerintah daerah/institusi, papan pengumuman resmi untuk masyarakat dan portal pengadaan.

Selain metode tersebut di atas, pengadaan barang/jasa dapat juga dilakukan dengan cara penunjukan langsung, mesiki pun nilai pengadaan barang/jasa tersebut lebih dari Rp.200.000.000,-( Dua Ratus Juta Rupiah )

Menurut Pasal 38 ayat (1) (satu) Perpres No. 54 Tahun 2010 Penunjukan langsung terhadap 1 (satu) barang/pekerjaan konstruksi/jasa lainnya dapat dilakukan dalam hal:

a. Keadaan tertentu ; dan/atau

b. Pengadaan barang khusus/pekerjaan konstruksi khusus/jasa lainnya yang bersifat khusus.

\section{Daftar Pustaka}

A.BUKU BUKU.

Agus kuncoro,menang tender pengadaan barang dan jasa pemerintah, jakarta 2011

Arifin P. Soeria Atmadja, Keuangan Publik dalam perspektif hukum, Rajawali Pers, Jakarta 2009

I Gusti Ayu Ketut Rahmi Handayani, Teori dan praktek legal drafting, cakrabooks solo, 2014

Lawrence M.Friedman,Teori dan filsafat

hukum:Telaah kritis atas teori teori hukum(susunan1), Judul asli lega theory, cetakan kedua, PT.Raja Grafindo Persada,Jakarta, 1993

M.Irfan Islamy, Prinsip-prinsip Perumusan Kebijakan Negara, Bina Aksara, Jakarta, 1996

Nyimas Dwi Koryati Dkk, kebijakan dan menejemen pembangunan wilayah, Yogyakarta 2005 
Soedarmin dan Subagio, Pengelolaan

Keuangan Negara, Jakarta,

1991

Teodore Lowi dalam Winarko,

Kebijakan Publik ( public

policy ), Bandung 2002

\section{B.UNDANG UNDANG DAN}

PERATURAN LAINNYA.

Undang Undang Dasar Negara Republik

Indonesia Tahun 1945

Undang Undang Nomor 1 tahun 2004 tentang Perbendaharaan Negara

Peraturan Pemerintah Nomor 6 Tahun 2006 tentang Pengelolaan

Barang Milik Negara/Daerah.

Perpres 54 tahun 2010 tentang

pengadaan barang/jasa

pemerintah 